Vol. 4, No. 3, 2019

\title{
ASSESSMENT OF THE ATMOSPHERIC AIR POLLUTION LEVEL IN KYIV
}

\author{
Olena Barabash, Viktoriia Khrutba
}

\author{
National Transport University, \\ 1, M. Omelianovycha-Pavlenka Str., Kyiv, 01010, Ukraine \\ el_barabash@ukr.net,viktoriia.khrutba@gmail.com
}

https://doi.org/10.23939/ep2019.03.156

Received: 04.08.2019

(C) Barabash O., Khrutba V., 2019

\begin{abstract}
Groups of plants, that regulate gas composition and the degree of air pollution, play a significant role in solving a complex spectrum of problems in the development of the modern city. The system "plant organism-urban environment" is indicative for the detection of dust pollution in atmospheric air of urban areas, manifesting the response of higher plants (morphological, anatomical, biochemical changes) used in urban landscaping.
\end{abstract}

Key words: atmospheric air, dust pollution, leaf blades, small-leaved linden (Tilia cordata Mill.).

\section{Introduction}

Woody vegetation of settlements plays a decisive role in determining the features of the state of the biosphere components (hydrosphere, lithosphere, and atmosphere) of the modern city. It regulates to some extent the gas composition of the air and the degree of its pollution, affects the climatic characteristics in urban areas, and reduces the level of noise factor. Modern scientists are conducting a number of studies related to the impact of urban environment on plant organisms, in particular the influence of dust load on green urban areas in Ukraine [1, 2, 3, 4], proposes modern approaches to combating dust pollution [5], considers the problems of landscaping [6, 7] and the possibilities of urban improvement management [8-10]. A special feature of dust is its ability to travel over long distances from the points of emissions caused by transport, industrial sites, and utility companies. The polluted atmospheric air affects plants changing the optical properties of the leaves; clogging, reducing the area and increasing the number of breaths per unit of leaf surface; inhibiting biosynthetic processes; irritating and slowing down plant growth, etc. [11]. Natural dust is in the air, in the usual habitat of people; its concentration does not exceed $0.1-0.2 \mathrm{mg} / \mathrm{m}^{3}$. In industrial centers where large enterprises are located, its concentration reaches $0.5 \mathrm{mg} / \mathrm{m}^{3}$ and above [3]. According to the project "Procedure for State Monitoring in the Field of Atmospheric Air Protection", dust (solid particles - $\mathrm{PM}_{10}$ and $\mathrm{PM}_{2.5}$ ) is included in the list of pollutants and is especially dangerous for the human body [12]. In this regard, it is of utmost importance to study the dust pollution of leaf blades of tree plantations for the timely prevention of negative changes in ecosystems occurring under the influence of anthropogenic activity. Therefore, the purpose of the study is to evaluate the level of dust pollution in the atmospheric air in Kyiv by the amount of dust on the leaves of the trees in the streets.

\section{Experimental part}

One of the most common species of woody plants in Kyiv - Tilia cordata, which is a part of the bioindication list of woody plants sensitive to the transformation of atmospheric components and resistant to changes in environmental quality, was selected as a phytoindicator in the experiment.

The study was conducted in August 2018 during the 10-day absence of precipitation. T. cordata leaves were collected at a height of $1.5 \mathrm{~m}$ with a 10 -fold repetition.

The study route ran through the areas with different anthropogenic load in ten administrative districts of Kyiv (Pecherskyi, Shevchenkivskyi, Podilskyi, 
Solomianskyi, Dniprovskyi, Desnyanskiy, Obolonskyi, Holosiivskyi, Sviatoshynskyi, Darnytskyi):

Site No. 1 is a street with heavy traffic;

, Site No. 2 - residential area;
, reference area - located in a relatively clean area of the city, away from the large concentration of roads and industrial enterprises - Holosiivskyi National Natural Park (NNP) (Table 1).

Total amount of $T$. cordata sampled material

Table 1

\begin{tabular}{|l|c|c|}
\hline \multicolumn{1}{|c|}{ Type of the studied territory } & $\begin{array}{c}\text { Number of } \\
\text { samples }\end{array}$ & $\begin{array}{c}\text { Number of } \\
\text { leaves }\end{array}$ \\
\hline Experimental areas (streets) of Kyiv near the highway: & & 100 \\
\hline Shevchenkivskyi (Peremohy Ave., Saksaganskogo St., O. Teligy Str.) & 20 & 100 \\
\hline Pecherskyi (M. Boychuk St., M. Omelyanovych-Pavlenko St., L.Ukrainka Str.) & 20 & 100 \\
\hline Holosiivskyi (Vel. Vasylkivska St., Nauky Ave., Holosiivskyi Ave.) & 20 & 100 \\
\hline Podilskyi (S. Bandera Ave., O. Teligy Str.) & 20 & 100 \\
\hline Desnyanskiy (V.Mayakovsky Ave., M.Zakrevsky St., T. Dreiser Str.) & 20 & 100 \\
\hline Dniprovsky (Bereznyakivska St., Yu. Gagarin Ave., Popudrenka Str.) & 20 & 100 \\
\hline Darnytskyi (Kharkiv square, Revutskogo Str, Kharkiv highway) & 20 & 100 \\
\hline Svyatoshynskyi (Les Kurbas Ave., Koltsov Blvd.) & 20 & 100 \\
\hline Obolonskyi (S. Bandera Ave., Obolonskyi Ave.) & 20 & 100 \\
\hline Solomianskyi (Vadim Hetman str., Vaclav Havel Str.) & 20 & \\
\hline Experimental areas (streets) of Kyiv near residential buildings: & 20 \\
\hline Shevchenkivskyi (Peremohy avenue, Brest-Litovskiy avenue, O. Teligi str.) & 100 \\
\hline Pecherskyi (I. Mazepa St., M. Boychuk St.) & 20 & 100 \\
\hline Holosiivskyi (avenue Acad. Glushkov, V. Vasylkivska, Zadorozhny lane) & 20 & 100 \\
\hline Podilskyi (O. Teligy St., Kopylivska St.) & 20 \\
\hline Desnianskyi (M. Tsvetaeva St., Radunska St., M. Zakrevsky St.) & 20 & 100 \\
\hline Dniprovskyi (Almatinskaya St., Berezniakivska St., Hnat Khotkevycha Street) & 20 & 100 \\
\hline Darnytskyi (Revutskogo str., Kharkivskoe shosse str.) & 20 & 100 \\
\hline Svyatoshynskyi (Les Kurbas Ave., Koltsov Blvd.) & 20 & 100 \\
\hline Obolonskyi (Obolonsky avenue, Marshal Tymoshenko str.) & 20 & 100 \\
\hline Solomianskyi (Garmatna Str., Vaclav Havel Street) & 20 & 100 \\
\hline Reference area: Holosiivskyi National Natural Park (NNP) & 20 & 100 \\
\hline Total: & 420 & 100 \\
\hline
\end{tabular}

Determination of environmental pollution with dust was carried out according to the proposed method [13]. In laboratory conditions, a piece of wet wool wrapped in tracing paper (up to $0.001 \mathrm{~g}$ ) was weighed. The linden leaves were carefully wiped with cotton wool on both sides by unfolding it (with tweezers) and weighed again with tracing paper. The dust mass $(\mathrm{P})$ was calculated as the difference between the first and second weighing ( $\mathrm{P}=\mathrm{P} 1-\mathrm{P} 2)$. The leaf area was calculated by measuring the leaf plates along (A) and across (B), multiplying by a factor K [13].

$$
\mathrm{S}=\mathrm{A} \times \mathrm{B} \times \mathrm{K}
$$

The factor ranges from 0.60 to 0.66 . The amount of dust was calculated using the formula:

$$
\mathrm{M}=\mathrm{P} / \mathrm{S}, \mathrm{mg} / \mathrm{cm}^{2} \text {. }
$$

As a reference area, during the research period, the indexes of leaf area and dust contamination of the linden leaf, which grows in a "conditionally" clean area with minimal technogenic loading in the Holosiivskyi NNP were considered.

\section{Results and discussion}

Systematic monitoring of the harmful substances content in the atmospheric air is carried out in the city of Kiev at 16 stationary posts (SP) with a sampling period of 6 days a week, 3-4 times a day. 20 contaminants are identified. 80367 samples were selected and analyzed to determine air pollution in 2018 [14]. According to the average annual concentrations of 20 contaminants in 2018 at 11 posts in the city, the level of pollution was estimated as high, while the values of the MPC for dust in the atmospheric air of Kyiv [7] were within the normal range and corresponded to the established MPC of $0.5 \mathrm{mg} / \mathrm{m}^{3}$. Such indicators testify to the difficult environmental situation in the city and cause deterioration of the human sphere of life.

It should be noted that fixed measurements carried out on the SP reflect only quantitative characteristics of the pollutants. Taking into account only quantitative values of the pollutants it is impossible to draw general conclusions about the ecological status of the city and 
suggest the measures required to ensure environmental safety. To make these measures effective, it is necessary to apply a comprehensive approach, which is not only to determine the degree of chemical pollution of the city, but also to be combined with the identification of the anthropogenic changes degree for a whole set of environmental factors, which play a crucial role in the formation of specific properties of soils, water objects and their resources and the atmospheric air in Kyiv. Therefore, the Ministry of Ecology and Natural Resources of Ukraine prepared a draft resolution of the Cabinet of Ministers of Ukraine "Certain issues of state monitoring in the field of atmospheric air", according to which the "Procedure of state monitoring in the field of atmospheric air protection" will be approved [5]. The new system of state monitoring is based on the implementation of the EU standard and model and is the implementation of the EUUkraine Association Agreement. Such changes are due to the need to reform the current atmospheric air monitoring system in order to be able to fully obtain up-to-date information on pollutant concentrations and take prompt response measures. The implementation of the monitoring system will ensure the right of Ukrainians to receive information on the state of the environment and enable citizens to participate in the development and formulation of policies to improve monitoring.

The launch of the monitoring system will provide the prompt collection and evaluation of the atmospheric air information for effective management decisions and control through established assessment modes depending on the levels of pollutants. The assessment mode for each pollutant is approved by the air quality management body according to the following criteria: the fixed measurement mode is applied if the pollutant level exceeds the upper assessment threshold; combined assessment mode is applied if the pollutant level is below the upper assessment threshold and is carried out by combining fixed measurements and a simulation method or by indicative measurements; the mode of estimation by modeling and objective methods, which is applied if the level of pollutants is below the lower threshold of assessment [5]. Concerning the mechanism of implementation of the State Monitoring Procedure in the field of atmospheric air protection "there may be considerable disputes related to the existing problems at the enterprises of Ukraine insufficient number of laboratories, technical facilities and qualified personnel in the field of monitoring studies. If the monitoring system is effectively launched, the following things will be established based on the data and information received: the level of the atmospheric air pollution in a certain territory for a certain period of time; compliance of the atmospheric air with the air quality requirements; control and assessment of the impact of measures aimed at limiting pollutant emissions into the air on the air quality, assessment of the impact of the air pollution on the environment, health and life of the population. Therefore, the combined assessment (fixed measurements in combination with bioindication methods) will allow to obtain an integrated assessment of the anthropogenic pressure on the ecosystem, and the use of higher plants to analyze their functional development features as dust pollution indicators (PM10, PM2.5) will provide additional information required to determine the condition of the ecosystem as a whole.

In terms of functional use, the territory of Kyiv is divided into residential, industrial and recreational areas, each of which has its own characteristics, purpose and is characterized by a certain impact on the environment. The residential area is characterized by high-rise buildings in the central right-bank part of the city, on new residential communities - Obolon, Vynogradar, Teremky, etc., on the Left Bank - the residential communities Troieshchyna, Kharkivskyi, as well as private buildings, which are located mainly on the outskirts of the city around its perimeter. The negative impact of this area on the environment can be estimated as average. The industrial area consists of industrial and motor transport enterprises. Within Kyiv, they are combined into industrial units and areas: PodilObolonskyi, Shulyavka, Nizhnyolybidskyi, Darnytskyi, and Telbinskyi. The negative impact of these areas on the environment is estimated as strong.

According to the results of the conducted research, the level of dust pollution and morphological changes of $\mathrm{T}$. cordata vegetative organs as one of the most common species of woody plants in Kyiv was established in the administrative regions (Table 2).

It is established that the tree plantations growing near the highway in Shevchenkivskyi district of Kyiv are characterized by the smallest leaf blade area (Fig. 1).

In comparison with the control, irreversible biochemical and physiological processes occur in plants during ontogenesis in the Shevchenkivskyi district during the development of vegetative organs of tree plantations and due to the action of emissions from the traffic, which is an invariable feature of this territory. They prevent the achievement of the standard sizes for $T$. cordata leaf blades, as it was detected in the area of complete absence of the road transport impact on the territory of Holosiivskyi National Natural Park (NNP).

The research found that leaf blades are the smallest in the residential area of Sviatoshynskyi, Dniprovskyi and Shevchenkivskyi districts of Kyiv, and woody vegetation has the best vegetative development indexes (the largest leaf blade area comparing with the reference area) in Holosiyivskyi, Desnianskiy and Obolonskyi districts. When comparing the area of leaf blades that were sampled in the area near the highway and in the residential area, it is found that the difference between the leave area near the road and near the residential area is the largest within the Holosiivskyi and Shevchenkivskyi districts, which indicates the extreme impact of emissions from road 
transport within these districts. It is important to note that an increase in leaf area, as we move into the middle of the residential area, is a characteristic sign that with sufficient landscaping of residential areas and their demarcation from highways with lanes of woody and shrub vegetation the state of soils, water resources and atmospheric resources is improving.

The next stage of the research was to determine the degree of dust pollution for leaf blade trees near hightraffic roads and within a residential area (Fig. 2).

Development status of $T$. cordata vegetative organs and dust pollution of atmospheric air in Kyiv

Table 2

\begin{tabular}{|l|l|l|l|l|l|}
\hline No. & \multicolumn{1}{|c|}{ Administrative district of Kyiv } & $\begin{array}{c}\text { Leaf area } \\
(\mathrm{S}) \\
{\left[\mathrm{cm}^{2}\right] \text { near }} \\
\text { the road }\end{array}$ & $\begin{array}{c}\text { Leaf area }(\mathrm{S}) \\
{\left[\mathrm{cm}^{2}\right] \text { near }} \\
\text { residential } \\
\text { buildings }\end{array}$ & $\begin{array}{c}\text { Determination } \\
\text { of pollution } \\
(\mathrm{M}) \\
{\left[\mathrm{mg} / \mathrm{cm}^{2}\right] \text { near }} \\
\text { the road }\end{array}$ & $\begin{array}{c}\text { Determination of } \\
\text { pollution }(\mathrm{M}) \\
{\left[\mathrm{mg}^{2} \mathrm{~cm}^{2}\right] \text { near }} \\
\text { residential } \\
\text { buildings }\end{array}$ \\
\hline 1 & Pecherskyi & 31.44 & 34.58 & 0.044 & 0.038 \\
\hline 2 & Darnytskyi & 30.52 & 33.66 & 0.052 & 0.041 \\
\hline 3 & Holosiivskyi & 30.53 & 36.25 & 0.052 & 0.034 \\
\hline 4 & Obolonskyi & 35.29 & 37.10 & 0.038 & 0.024 \\
\hline 5 & Solomianskyi & 28.41 & 32.31 & 0.054 & 0.036 \\
\hline 6 & Shevchenkivskyi & $\mathbf{2 6 . 6 0}$ & 31.79 & $\mathbf{0 . 0 8 8}$ & $\mathbf{0 . 0 6 4}$ \\
\hline 7 & Desnianskyi & 30.87 & 35.17 & 0.042 & 0.041 \\
\hline 8 & Podilskyi & 28.79 & 32.23 & 0.042 & 0.035 \\
\hline 9 & Dniprovskyi & 28.83 & 31.96 & 0.046 & 0.040 \\
\hline 10 & Svyatoshinskyi & 27.23 & $\mathbf{3 1 . 7 5}$ & 0.057 & 0.041 \\
\hline Reference area: Holosiivskyi NNP & & $\mathbf{5 1 . 9 3}$ & & $\mathbf{0 . 0 0 9}$ \\
\hline
\end{tabular}

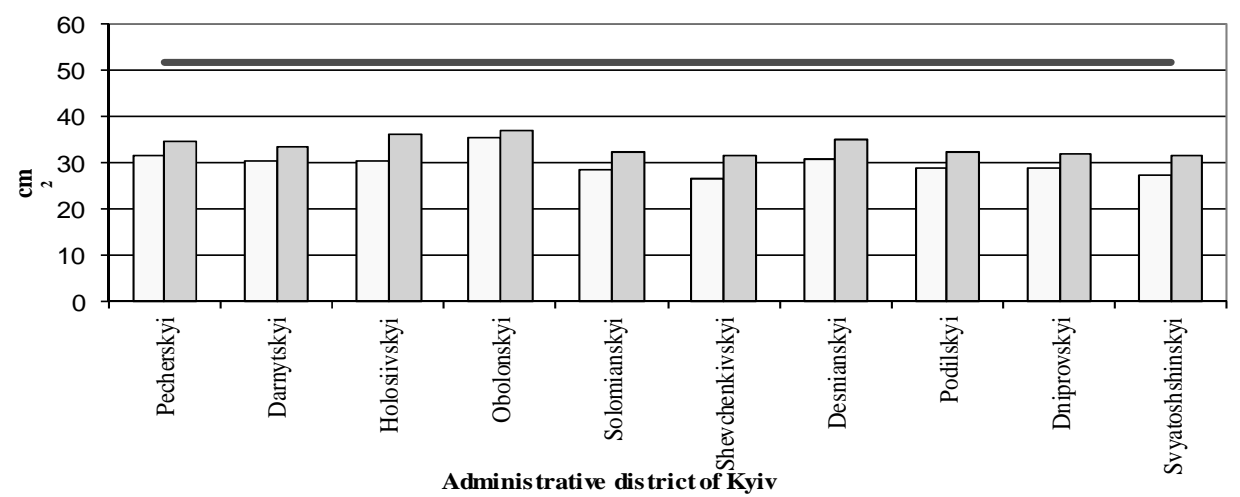

$\square$ Area near the road $\square$ Area near residential buildings $\longrightarrow$ NNP "Holosiivskyi"

Fig. 1. Leaf blades area (road and residential zone)

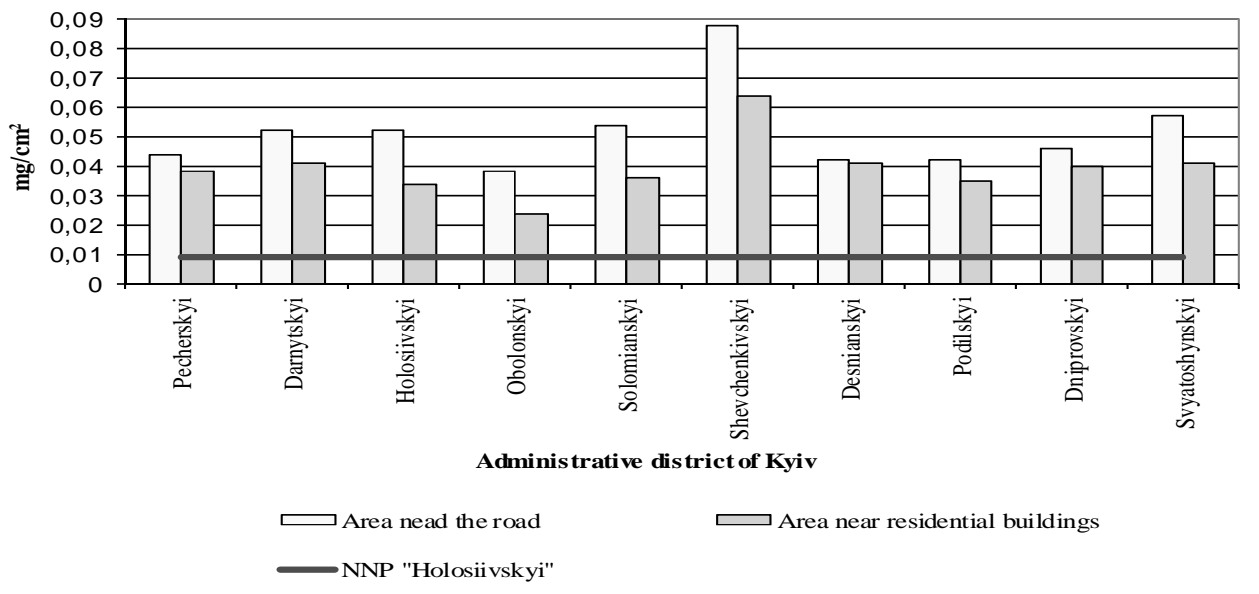

Fig. 2. Dust pollution of leaf blades (road and residential areas) 
The obtained results regarding the level of dust contamination of $T$. cordata leaf blades near the road, when compared with the indicators obtained in the "Holosiivskyi" NNP showed that the excess of dust compared to reference area was almost 10 times higher in Shevchenkivskyi district, 6 times higher in Svyatoshinskyi and Solomianskyi districts, 5 times higher in Darnytskyi and Holosiyivskyi districts. Dust loading of leaf blades in the residential area compared to the reference area is of great concern, since the minimum level of dust pollution is observed only in the Obolon residential area, but even this result 3 times exceeds the reference value.

\section{Conclusions}

It was found that fixed measurements as traditional environmental monitoring methods do not show the real situation of the ecosystem, since they do not provide complete information about the real state and response of ecosystem components to the actual impact of stationary and mobile sources. The data obtained as a result of fixed measurements is primarily a chemical control of the concentration of pollutants and a statement of the fact of compliance or non-compliance with the requirements set out in the regulatory documents. The objective assessment of the ecosystem state is directly related to the "response" of the ecosystem to anthropogenic influence. The revealed critical deviations of leaf blade morphological parameters from their optimal (reference) values and the high degree of the dust pollution characterize Kyiv as an anthropogenic and technogenic urban area that is not only inappropriate for the growth and development of tree plantations but can also have a significant negative impact on the quality of life and public health.

\section{References}

[1] Kucheryavyy V. P. Problemy urboekolohiyi, NMKVO, Kyiv, 1992, 3. (in Ukrainian)

[2] Margaylik G. P. Botanicheskiy zhurnal, 1965, 1, 89. (in Russia)

[3] Hanaba D. V. Visnyk Cherkas'koho universytetu, 2015, 19, 55. (in Ukrainian)

[4] Sytnikova I.O., Radul I.P. "Achievement of high school", Ukraine, Chernivtsi, 2013, 61.

[5] Vasylkivskyy B. M. Zbalansovani mista: vprovadzhennya idey zelenoho planuvannya, proektuvannya ta budivnytstva v Ukraini, Ukraine, Kyiv, 2018, 4.

[6] Margaylik G. I. Spravochnik ozelenitelya. Polymya, Minsk, 1999, 144. (in Bilorus)

[7] Timothy Beatley Green Cities of Europe. Global Lessons on Green Urbanism. IslandPress, London, 2012, 243 (in England)

[8] Khotuntsev Yu. L. Ekologiya ekologicheskaya bezopasnost'. Akademiya, Moskva, 2004, 480. (in Russia)

[9] Povolots'ka I. V. Okhorona navkolyshn'oho seredovyshcha ta ratsional'ne vykorystannya pryrodnykh resursiv, Ukraine, Donetsk, 2010, 18.

[10] Zanadvorov V.S. Ekonomika goroda. IKTS "Akademkniga", Moskva, 2003, 435 c. (in Russia)

[11] Bakharev V. S. Visnyk KDPU, 2005, 12 (31), 92. (in Ukrainian)

[12] https://menr.gov.ua/files/docs/Proekt/28012019/ Proekt.pdf

[13] Beyko I. V., Boholyubov V. M., Vyshens'ka I. H. Laboratornyy ta pol'ovyy praktykum z ekolohiyi, Fitosotsiotsentr, Kyiv, 2000, 216. (in Ukrainian)

[14] Tsentral'na heofizychna observatoriya im. Borysa Sreznevs'koho http://cgo-sreznevskyi.kiev.ua/index.php 